\title{
Sodium requirement of milking cows: balance trials with cows on rations of freshly mown herbage and on winter rations
}

\author{
A. KEMP \\ Institute for Biological and Chemical Research on Field Crops and Herbage, \\ Wageningen, Netherlands
}

\begin{abstract}
Summary
Balance trials have been carried out with milking cows fed on freshly mown herbage or winter rations. Data are available on the sodium intake, sodium excretion in faeces and urine, and secretion in the milk of cows in 12 experiments (Table 1 and 2). Moreover, data have been collected and discussed on the influence of supplementary $\mathrm{KCl}$ on the excretion of sodium in urine and faeces.

The sodium intake with freshly mown herbage and drinking water varied from 5,8 to $91,0 \mathrm{~g}$ a day, $14,5 \%$ of which was excreted in the faeces. The "availability" of the sodium ingested, accordingly, averaged $85,5 \%$ varying from 77 to $95 \%$.

Supplementary $\mathrm{KCl}$ increased sodium excretion in the urine, while that in the faeces decreased. Accordingly, total-sodium excretion did not change. Increased sodium excretion in the urine mainly took place during the first few days after $\mathrm{KCl}$-application (Table 3 and Fig. 2). The data suggest that due care should be taken in accepting the common view that increased potassium intake by the animal should lead to sodium impoverishment of the body.

There is a close correlation between the sodium ingested and the excretion of urinary sodium (Fig. 3). The sodium secretion in the milk averaged $0,38 \mathrm{~g}$ per 1 , varying from 0,31 to 0,49 per 1 . With sufficient and high sodium intakes, retentions were rather highly positive (Fig. 4 and 5). Probably this was due to other sodium excretions than those normally determined in balance trials, possibly by transpiration through the skin and loss of saliva. With normal sodium intakes this additional sodium excretion appeared to average $2,5 \mathrm{~g}$ a day (Fig. 6). When sodium excretion in the urine was below $3 \mathrm{~g}$ a day retentions were negative.

The "maintenance requirement" was approximately $5,5 \mathrm{~g}$ of "available sodium" per day (Fig. 6). The daily requirement of herbage sodium for milk yields of $25 \mathrm{~kg}$ per day and for an "availability" of herbage sodium of $85 \%$ was approximately $18,2 \mathrm{~g}$ (Table 4).
\end{abstract}

\section{Introduction}

In the middle of the last century the importance of a sufficient sodium supply to man and animal was investigated. BuNGE's work (1873) is particularly well-known; he payed special attention to the great salt requirement of herbivores and to the salt impoverishment of the body possibly due to the relatively high contents of potassium in the herbage rations. Modern literature still shows the effects of BungE's ideas, which are expressed in the generally accepted view that the sodium requirement of animals increases as potassium intake with the rations increases.

So far, few data are known about the sodium requirement of lactating cows. A small

Received for publication 20th March, 1964.

Neth. J. agric. Sci., Vol. 12 (1964) No. 4 (November) 
number of experimental animals was generally used in investigations and these were generally fed on winter rations. During the last few years a great many trials have been carried out in behalf of our investigations on hypomagnesaemia in dairy cows, grazing experiments as well as balance trials (KEMP, 1958, 1960; KEMP et al., 1961). Magnesium was the most important element in these experiments, so that it proved possible to obtain clear views on the magnesium requirement of milking cows in relation to the incidence of hypomagnesaemia. During these investigations also data were collected on other mineral elements amongst which sodium. This publication deals with the data of 12 balance trials.

\section{Experiments}

In 10 experiments the animals were barn-fed on rations solely consisting of freshly mown herbage and in two experiments on winter rations. The rations were composed according to the feeding standards used in the Netherlands (C.V.B., 1956). The most important data on the plan of these experiments are mentioned in TABLE 1. Lactating Friesian cows were used with a milk yield varying from 6 to $22 \mathrm{~kg}$ per cow per day. One experiment, exp. 12, was carried out with dry cows not in calf. The experimental animals varying in age from 5 to 9 years were in good condition and had not suffered from any metabolic disorders in the months preceding the experiments.

The separate collection of faeces and urine was carried out according to the method of VAN Es and VoGT (1959). Urine losses in the faeces did not average more than 1 to $2 \%$ of the total urine production; contamination of the urine with faeces seldom occurred. In a few experiments faeces and urine were separately collected by means of a balloon catheter, similar to the one used by CunNingHAM et al. (1955). This method, however, gave difficulties because the bladder was readily damaged. More elaborate data concerning the experimental routine and sampling are to be found in an earlier publication (KEMP et al., 1961).

\subsection{Details of the rations fed}

Data on the milk yield of the experimental animals, the dry-matter intake and the contents of potassium, sodium and crude protein in the dry matter are mentioned in TABLE 1. The sodium contents in the herbage varied from 0,05 to $0,91 \%$ of dry matter, the potassium contents from 1,57 to $4,08 \%$. These wide variations were obtained by fertilizing the fields with varying amounts of muriate of potash and nitrogen, the latter in the form of nitro-chalk or chilean nitrate. The differences in the crude-protein content are due to the application of diverging amounts of nitrogenous fertilizer as well to mowing at different stages of growth. In most of the experiments the herbage was cut at the same early stage as when cattle are usually put to pasture.

Exp. 2 and 3: The same cows were used in both experiments. Cows 1 and 4 in exp. 2 received herbage with a lower sodium content than cows 2 and 3 . This was the reverse in exp. 3. In both experiments the interval between collections was only 2 days. This was done to check any changes in the composition of the urine during rapid changes from one ration to another.

Exp. 4, 5 and 6: The same cows were used in these three experiments. The sodium contents in the herbage of exp. 4 and 6 were considerably higher than those in the herbage of exp. 5. This was due to fertilisation of the experimental fields with chilean nitrate. 
Exp. 7: During this experiment cows 1 and 4 were fed on herbage with a higher crude-protein content $(18 \%)$ than cows 2 and $3(12 \%)$. The herbage came from the same field which had been divided into two plots fertilized with different amounts of nitrogen. The sodium contents of the herbage were high and highest on the plots most heavily fertilized with nitrogen.

Exp. 9, 10 and 11 : Cows 3 and 4 in exp. 9 were the same animals as in exp. 10 and 11. During the three subsequent experiments these animals consumed grass of the same pastures, but each time in an older growth stage. As the herbage matured the content of crude protein decreased considerably, and was 26,18 and $14 \%$ respectively in the herbage of the three subsequent experiments (TABLE 1).

Exp. 12: This experiment was carried out with dry, winter-fed cows not in calf. In all three periods $A, B$ and $C$ the same rations consisting of $5 \mathrm{~kg}$ hay and $2,5 \mathrm{~kg}$ oat meal per cow per day were supplied. However, during the preliminary period and the collection period of exp. $12 \mathrm{~B}$ both cows received $400 \mathrm{~g}$ of $\mathrm{KCl}$ per cow per day in pellets. These pellets of $25 \mathrm{~g}$ were supplied three times a day, i.e. at 8.00 , 14.00 and 22.00 hours by means of a "dosing gun".

Exp. 13: The six cows in exp. $13 \mathrm{~A}$ all recieved the same herbage. The experiment was continued with 2 cows, viz. cows 5 and 6 , in exp. $13 \mathrm{~B}$ and $13 \mathrm{C}$. In all three periods grass of the same pasture was fed, although in various growth stages similar to exp. 9, 10 and 11 . The crude-protein contents in the herbage during the three periods were 17,13 and $11 \%$ respectively. The sodium contents in the herbage were very low and decreased as the herbage matured.

Exp. 14: In the three periods $\mathrm{A}, \mathrm{B}$ and $\mathrm{C}$ of this experiment the cows received the same winter rations consisting of : $10 \mathrm{~kg}$ hay for cows 1,3 and 4 , while cow 2 received $8 \mathrm{~kg}$ hay. All animals received $2 \mathrm{~kg}$ of beet pulp and $1,5 \mathrm{~kg}$ of maize meal. Cows $1,2,3$ and cow 4 received $3 \mathrm{~kg}$ and $3,5 \mathrm{~kg}$ of concentrates respectively. During the preliminary and the collection period in exp. $14 \mathrm{~B}$ all cows received $420 \mathrm{~g}$ of $\mathrm{KCl}$ per cow per day. The $\mathrm{KCl}$ was supplied 5 times a day in the same way as in exp. 12 at $6.00,10.00,14.00,18.00$ and 22.00 hours.

\section{Results}

3.1. Sodium intake, excretion in the faeces and urine and secretion in the milk

Data on the daily intake of sodium, the excretion of sodium in the faeces and urine and secretion in the milk are mentioned in TABLE 2. The intake of sodium includes the sodium in the drinking water.

In the experiments with freshly mown herbage the daily sodium intake varied from 5,8 to $91,0 \mathrm{~g}$. This wide variation is due to the large differences in the sodium content of the herhage and to differences in the dry-matter intake of the animals. The sodium excretion in the faeces averaged about $14,5 \%$ of the intake; the average "availability" consequently is $85,5 \%$ ("Availability" is the percentage of sodium ingested which is not excreted in the faeces). The percentage varied from 77 to $95 \%$. There was less "availability" of sodium in winter rations, this varying from 46 to $86 \%$ and averaging $68 \%$. RooK and BALCH (1962) found an "availability" of $78 \%$ in milking cows on herbage rations varying from 66 to $94 \%$. On winter rations they found an averaged of $73 \%$ within a range of 36 to $85 \%$. The variation in the "availability" of herbage sodium may be due to many factors. It is stated that cows with scour are supposed to excrete relatively more sodium in the faeces. Although 


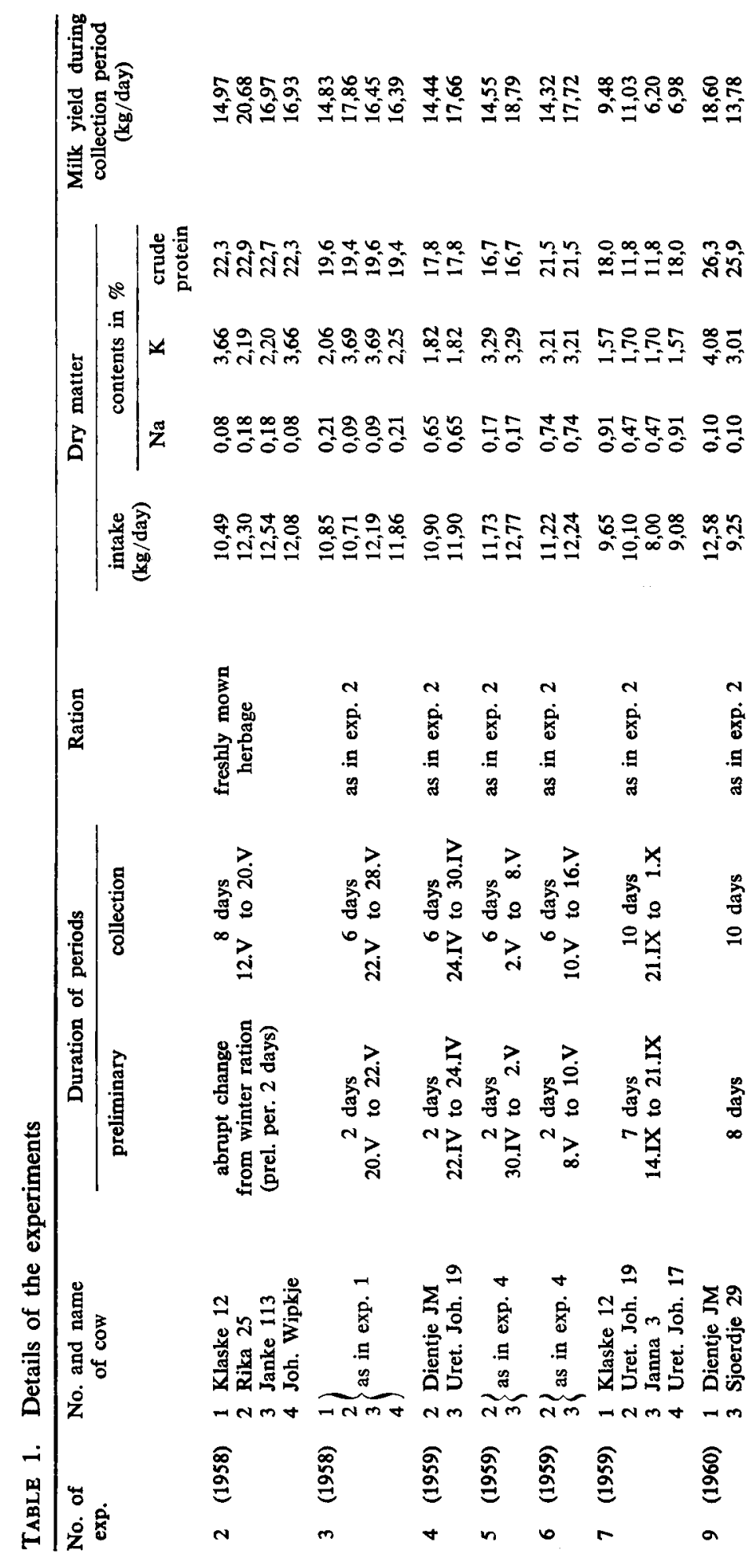


A. KEMP




in our experiments the dry-matter percentages in the faeces of the cows on herbage rations sometimes were very low and varied from 8 to $14 \%$ and on winter rations from 14 to $19 \%$, no influence could be shown on the sodium excretion in the faeces. This suggests that scour is not necessarily related to increased sodium excretion in the faeces.

Probably, "availability" is related to the amount of sodium ingested. The data in FIG. 1 suggest that the lowest "availability" is found at the lowest sodium intake and in any case not at the highest.

FIG. 1. Relation between sodium ingested and "availability" of sodium in milking cows



The data represented in FIG. 1 only relate to experiments with freshly mown herbage. The fact that the lowest "availability" was found at the lowest sodium intake, and vice versa, might be explained by the amount of endogenous faecal sodium in relation to the total amount of faecal sodium. This ratio may be related to the amount of sodium ingested by the animal. Probably the amount of endogenous faecal sodium is relatively larger at very low sodium intakes compared to high sodium intakes. A certain quantity of endogenous sodium will always be excreted in the faeces. At very low sodium intakes this quantity could relatively be so large that the pgrcentage of sodium ingested, not excreted in the faeces ("availability") decreases. However, this does not imply that true availability will also decrease at low sodium intakes.

Another factor that seems to influence the sodium excretion in the faeces and urine is to give the animals supplementary $\mathrm{KCl}$. Exp. 12 and 14, which in contrast to all other experiments were carried out on winter rations, proved that application of $400 \mathrm{~g}$ of supplementary $\mathrm{KCl}$ per cow per day in exp. 12 and of $420 \mathrm{~g}$ in exp. 14 considerably decreased the sodium excretion in the faeces, while that in the urine of most animals increased (TABLE 2). TABLE 3 shows the average data on sodium intake, total excretion, excretion in faeces and urine, and the urine production during the three periods A, B and C. As has already been mentioned, exp. 12 was carried out with dry cows not in calf and exp. 14 with dairy cows. 
SODIUM REQUIREMENT OF MILKING COWS: BALANCE TRIALS WITH COWS ...

Table 3. The influence of supplementary $\mathrm{KCl}$ on sodium excretion in the faeces and urine of dairy cows

\begin{tabular}{|c|c|c|c|c|c|c|}
\hline & \multicolumn{4}{|c|}{ Sodium in $\mathrm{g} /$ day } & \multirow{3}{*}{$\begin{array}{l}\text { Dry matter } \\
\text { in faeces } \\
(\%)\end{array}$} & \multirow{3}{*}{$\begin{array}{c}\text { Urine } \\
\text { produced } \\
\text { (kg/day) }\end{array}$} \\
\hline & \multirow[t]{2}{*}{ intake } & \multicolumn{3}{|c|}{ excretion } & & \\
\hline & & total & in faeces & in urine & & \\
\hline $\begin{array}{ll}\text { Exp. } 12 & \mathrm{~A} \\
+\mathrm{KCl} & \mathrm{B} \\
& \mathrm{C}\end{array}$ & $\begin{array}{l}17,5 \\
17,7 \\
17,5\end{array}$ & $\begin{array}{l}14,7 \\
16,4 \\
16,4\end{array}$ & $\begin{array}{l}3,4 \\
2,0 \\
4,5\end{array}$ & $\begin{array}{l}11,3 \\
14,4 \\
12,0\end{array}$ & $\begin{array}{l}18,68 \\
16,88 \\
18,03\end{array}$ & $\begin{array}{r}4,58 \\
15,19 \\
5,05\end{array}$ \\
\hline $\begin{array}{r}\text { Exp. } 14 \mathrm{~A} \\
+\mathrm{KCl} \\
\quad \mathrm{B}\end{array}$ & $\begin{array}{l}17,7 \\
18,6 \\
16,7\end{array}$ & $\begin{array}{l}18,1 \\
15,1 \\
14,6\end{array}$ & $\begin{array}{l}7,2 \\
4,1 \\
5,4\end{array}$ & $\begin{array}{l}5,7 \\
6,6 \\
5,1\end{array}$ & $\begin{array}{l}14,31 \\
13,70 \\
14,57\end{array}$ & $\begin{array}{l}12,93 \\
24,09 \\
13,33\end{array}$ \\
\hline
\end{tabular}

During the three subsequent collection periods $\mathrm{A}, \mathrm{B}$ and $\mathrm{C}$ the quantities of sodium ingested were almost the same. The somewhat higher sodium intake in exp. $12 \mathrm{~B}$ with regard to exp. $12 \mathrm{~A}$ and $12 \mathrm{C}$ is due to the higher water intake as a result of the potassium application which had already started at the beginning of the preliminary period. This higher water intake was also evident from the larger urine production, while the dry-matter percentages in the faeces were lower. The differences in sodium intake were somewhat larger in exp. 14 due to differences in the drymatter intake of the animals. In both experiments the $\mathrm{KCl}$-application was associated with a decrease in the sodium excretion in the faeces and an increase in urine-sodium excretion. In this case there is no connection between a decrease in the dry-matter content of the faeces and an increase in faecal-sodium excretion. The increase in sodium excretion in the urine did not occur with all animals (TABLE 2). As will be shown below, this effect may actually have occurred, but only during the preliminary period, because the increase will be largest in the first few days. Averaged for all animals, the increased urinary-sodium excretion due to supplementary $\mathrm{KCl}$ was about as large as the decrease in sodium excretion in the faeces, so that the values for retention did not change.

In connection with the above it would be interesting to investigate whether the increased sodium excretion in the urine due to additional potassium is only a temporary effect or a permanent one. In exp. 12 the influence of supplementary $\mathrm{KCl}$ was investigated from the first to the fourteenth day after its application, in exp. 14 from the seventh till the fifteenth day (TABLE 2 and 3 only show data on exp. 12 and 14 collected during the collection period).

In exp. 12 urinary-sodium excretion was determined every two days after the application of supplementary $\mathrm{KCl}$ had started (FIG. 2). From this it was evident that increased sodium excretion, due to additional $\mathrm{KCl}$, took place especially during the first few days after application. Despite the fact that supplementary $\mathrm{KCl}$ was continued, this excretion decreased again considerably after a few days and with cow 2 even to approximately the same level as before the application of $\mathrm{KCl}$. Moreover, both animals temporarily showed a considerably decreased urine-sodium excretion immediately after terminating supplementary $\mathrm{KCl}$, viz. from 30th November to 3rd December. Soon after, the sodium excretion returned to the same level as before the KCl-supplementation. In elaborate experiments with pigs and rats MrLLER (1923 a, b; 1926) also found clearly increased urinary-sodium excretions after the application of potassium. Here too, the largest effect was observed in the first few days after 
FIG. 2. Influence of supplementary $\mathrm{KCl}$ on excretion of sodium in dairy cows
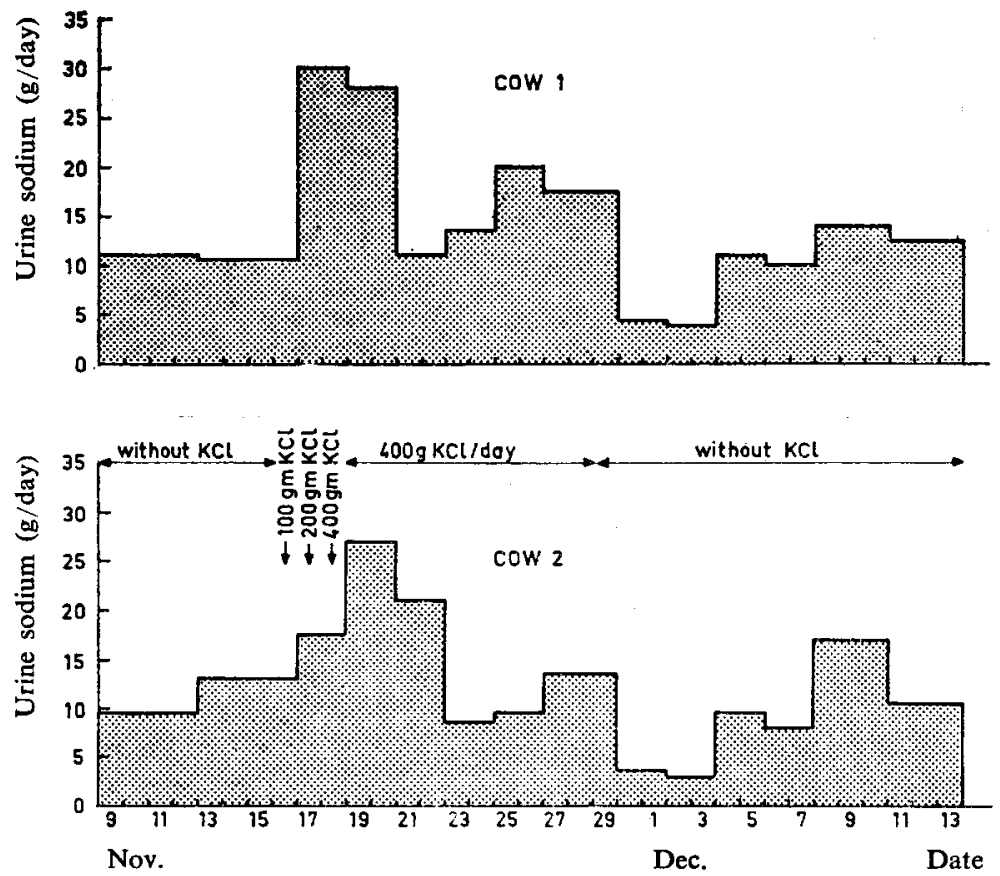

supplementation. Despite the fact that supplementary potassium was continued, in this case urine-sodium excretion also decreased to almost the same level as before the potassium supply. DE Groot (1961) found the same in dairy cows. The same investigators also observed a temporarily much decreased excretion of sodium after terminating the additional potassium supply. Thus, these data are in complete agreement with the results mentioned in FIG. 2 of exp. 12 .

In summarizing the results of the experiment just mentioned, it may be concluded that supplementary $\mathrm{KCl}$ will result in a temporary increase in urine sodium. This increased excretion decreases again after a few days until almost the same level is reached as before supplementary $\mathrm{KCl}$ was given. In prolonged experiments, however, it is quite possible that this effect disappears completely, or is limited to extremely small differences despite the fact supplementary $\mathrm{KCl}$ is continued. Apparently, the animal body can soon adapt itself to a sudden change in conditions.

These data are also interesting in relation to BuNGE's hypothesis (1873). He suggested that sodium impoverishment of the body might occur due to increased urinary-sodium excretion caused by increased potassium intake in the feed. It should be taken into account, however, that BUNGE's considerations are based on one-day experiments upon himself. He did prove an increased excretion of urinary sodium due to the application of various potassium salts, but these experiments lasted only one day and, moreover, no data were collected on the sodium excretion in the faeces. It was indeed proved that this effect was due to potassium as this was supplied in the form of various salts, among which $\mathrm{KCl}$, all showing the same effect. BuNGE s views (1873) however could not be confirmed in our experiments, because the increased urine- 
sodium excretion due to supplementary $\mathrm{KCl}$, was compensated by a decreased faecalsodium excretion. Accordingly, no change was observed in the total excretion of sodium. The later has already been proved by RICHARDs et al. (1927) in experiments with pigs. In these experiments the increased excretion of urinary sodium due to supplementary potassium, was also compensated by a decreased excretion in the faeces. The investigators found the same effect on the potassium excretion due to supplementary sodium (RICHARDs et al., 1924). In experiments with rats Miller (1923 a, b), SCHOORL (1934) and GrunerT et al. (1950) found that the sodium requirement of these animals did not increase by increasing the potassium content in the rations. All these data suggest that due care should be taken in accepting the common view that increased potassium intake by the animal should lead to sodium impoverishment of the body.

In our experiments urinary-sodium excretion varied from 0,4 to $72,9 \mathrm{~g}$ per day (TABLE 2). The amount of this excretion was mainly determined by the sodium intake in the rations as has been shown in FIG. 3 .

From FIG. 3 it appears that a linear relationship exists between the urine-sodium excretion and the intake of 15 to $90 \mathrm{~g}$ of sodium per day. When the intake is less than $15 \mathrm{~g}$ a day, the gradient of the line will change and there is not such a sharp decrease in the excretion. With an intake of less than $10 \mathrm{~g}$ the excretion of sodium in the urine will be less than $2 \mathrm{~g}$ a day. The sodium contents in the urine varied from 20 to $3910 \mathrm{mg}$ of sodium per litre (average content of the total urine production during a collection period). The sodium concentration in the urine as well as the quantity excreted by the same animal may fluctuate sharply within 24 hours. A cer-

Frg. 3. Correlation between sodium intake and excretion in urine in dairy cows

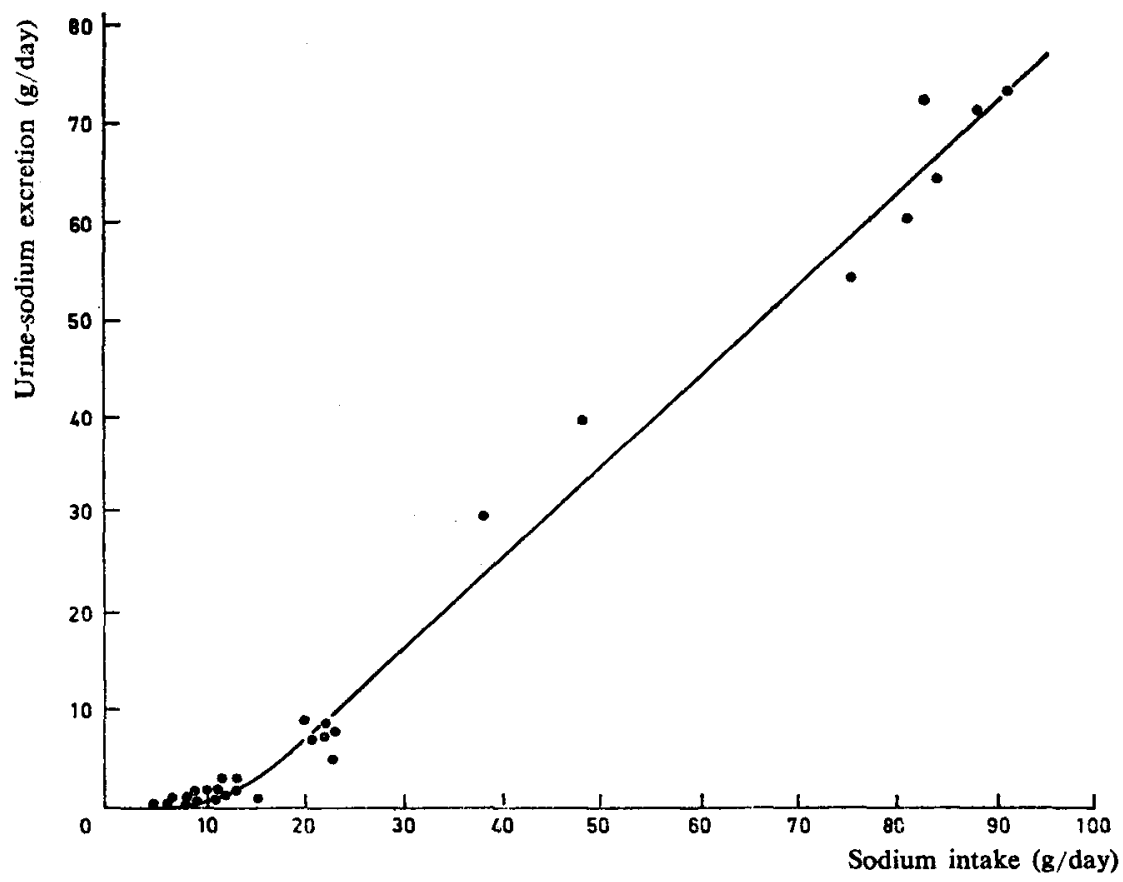


tain rhythm was also observed in the quantity of sodium excreted within 24 hours (unpublished data).

In this investigation no indications were found that more sodium is excreted in the urine of cows with high milk yields than with low ones. The sodium content in the milk averaged $0,38 \mathrm{~g}$ per litre, varying from 0,31 to $0,49 \mathrm{~g}$. There are considerable differences between animals.

MULDER et al. (1959) determined the contents of mineral elements in milk of four cows during the whole lactation period. Every day or every two days the sodium contents were also determined. In the periods with milk yields over $15 \mathrm{~kg}$ per day they found an average content of $0,36 \mathrm{~g}$ of sodium per litre varying from 0,28 to $0,52 \mathrm{~g}$ per litre. These contents are almost the same as those found in our experiments. With very low milk yields different values should be used because the sodium contents in the milk will be higher in that case.

Although the influence of sodium intake on the sodium contents in the milk seems to be small, some indications were found that with very low intakes the sodium contents in the milk show a slight decrease, similar to that observed by RENKEMA et al. (1962).

\subsection{Sodium requirement}

Data of balance trials enable the estimation of the herbage sodium required for maintaining a balance in the body of the animal between sodium intake and excretion. Accordingly, this is the minimum requirement. In the same way as this was done for magnesium (KEMP et al., 1961), this is shown for sodium in FIG. 4.

The values shown on the $\mathrm{X}$-axis of FIG. 4 were found by subtracting the sodium secreted in the milk from the "available" herbage sodium ( $\mathrm{Na}$-feed minus $\mathrm{Na}$-faeces minus Na-milk). The values thus obtained were plotted against the daily excretion of urinary sodium. The retention can also be read from this figure. The dashed line forming an angle of $45^{\circ}$ with the $\mathrm{x}$-axis shows all points at which sodium intake is on a level with sodium excretion. Accordingly, the retention is zero. When "available" sodium minus sodium required for secretion in the milk is larger than the quantity excreted in the urine, the points will lie below the dashed line and the retention will be positive. On the other hand, the retention will be negative when the "available" sodium is less than that of urinary sodium and then the points lie above the dashed line. The latter is the case only on the left hand side of the figure. Here the value for Na-feed minus Na-faeces minus Na-milk is so small that the positive retention changes into a negative one and thus sodium impoverishment of the body takes place. At this change the solid line intercepts the interrupted one. As it was not possible to show all observations clearly in FIG. 4, the observations from the most important part of that figure were transferred to FIG. 5 on a larger scale.

Fig. 5 proves that retention will be zero when the amount of "available" sodium minus sodium required for the milk is about $0,5 \mathrm{~g}$ a day.

In FIG. 4 two points are shown by a solid triangle. These data relate to cows 1 and 4 from exp. 3 (TABLE 2). In this experiment these cows received considerably more herbage sodium than in exp. 2. Sodium was retained in the body as a consequence of the sodium-rich nutrition in exp. 3 after the sodium-poor nutrition in exp. 2. This is expressed in the higher values for retention, while the excretion of urine sodium remains on a low level. A similar effect, i.e. the use of body sodium and the subsequent replenishment of it, has also been observed by ScHoorL (1934) in experiments with rats. With cows 1 and 4 in exp. 3, however, this replenishment 
Fig. 4. Correlation between "available" sodium minus sodium secreted in milk (x-axis) and sodium excreted in urine (y-axis)

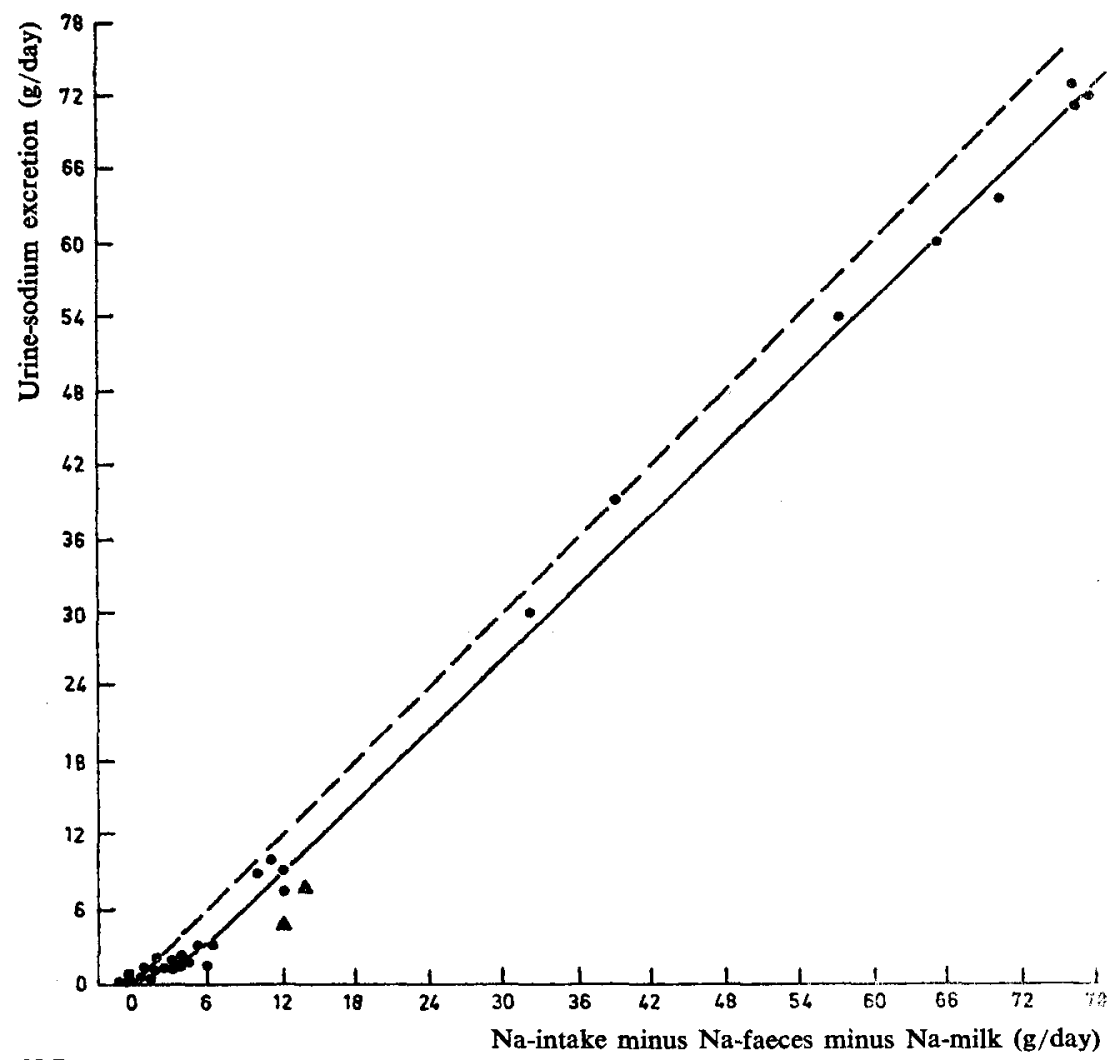

N.B.

Solid triangles denote sodium-poor nutrition in the preliminary period.

follows after a period in exp. 2 in which retentions are not negative, suggesting replenishment was not necessary at all. Nevertheless, it may be assumed that retentions were in fact negative. Moreover, probably all values mentioned in TABLE 2 for "retention" are not accurate but too high.

In FIG. 4 and 5 the regression line (solid line) is under the dashed line, which means that the retention continuously fluctuated between 2,5 and $5 \mathrm{~g}$ of sodium per day with sodium-rich nutrition. For two reasons however these high retenttions are improbable, viz. firstly because the experiments were carried out with adult animals which usually do not have these high daily sodium retentions, and secondly it may be assumed that sodium is also excreted in other ways than is normally determined in balance trials. Most likely, sodium is also excreted by transpiration through the skin, while also some sodium will be lost with the saliva.

According to Ferguson and Dowling (1955) water excretion through the skin may be estimated at $3,3 \mathrm{~kg}$ per 24 hours for a cow with a body weight of $450 \mathrm{~kg}$ at a temperature of $10^{\circ} \mathrm{C}$. This value varies widely with fluctuations in temperature. No true data are known on the sodium content in sweat of cattle. Investigations of 
FIG. 5. Correlation between "available" sodium minus sodium secreted in milk (x-axis) and sodium excreted in urine ( $y$-axis)

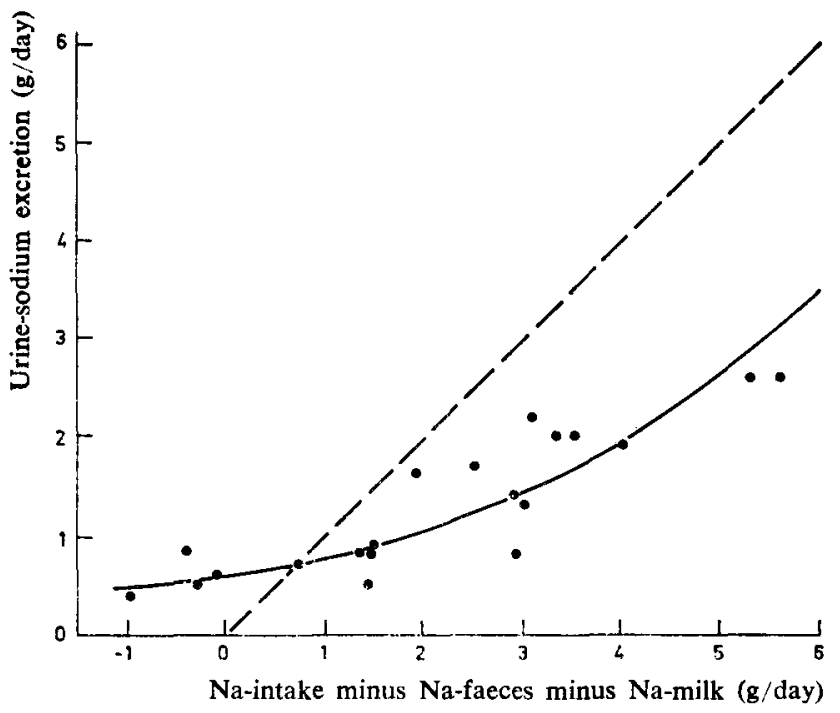

BARRISON et al. (1951) and Ferguson and Dowling (1955) have indeed proved that sweat of cattle contains chloride. Only MANGOLD (1932) states that the sodium content of sweat may possibly vary from 1 to $5 \mathrm{~g}$ of sodium per litre. He did not mention however where and how these values were determined. In view of the rather considerable quantities of water which have been proved to contain chloride and may be excreted through the skin, it may be assumed that cattle does excrete sodium through the skin, and that this might amount to a few grams a day. Furthermore, it is quite possible that sodium is also excreted in saliva losses, though probably these will be still less. Nevertheless, if the daily saiiva production contains approximately $100 \mathrm{~g}$ of sodium, there will be an additional sodium loss of $1 \mathrm{~g}$ a day due to a saliva loss of $1 \%$ per day. Both last mentioned factors, viz. sodium loss through the skin and by saliva loss, could account for the "positive retention" in FIG. 4 and 5 . Considering these additional excretions, balance trials with adult cattle in which normally only the sodium excretion in faeces and urine and sometimes the secretion in milk are determined, will probably always show positive retentions that are in fact not accurate. Most likely, the data on retention in TABLE 2 will all be too high and should be interpreted likewise. In FIG. 4 retention averages about $2,5 \mathrm{~g}$ of sodium a day with a value of $6 \mathrm{~g}$ on the $\mathrm{x}$-axis, increasing to approximately $5 \mathrm{~g}$ a day with sodium-rich nutrition. In view of the preceding, a higher sodium content in the sweat and maybe also in saliva could account for this at higher sodium intakes.

These additional losses should also be taken into account when calculating the sodium requirement of cattle. In order to correct the values on the $\mathrm{X}$-axis in FIG. 4 and 5, $2,5 \mathrm{~g}$ of sodium are put down to "other excretions" in FIG. 6. The fact that this correction should be about $5 \mathrm{~g}$ at higher sodium intakes, is left out of consideration in this case as the sodium requirement will always be sufficiently covered at these high sodium intakes. 
FIG. 6. Correlation between "available" sodium minus sodium secreted in milk minus $2,5 \mathrm{~g}$ of sodium for "other excretions" and sodium excreted in urine

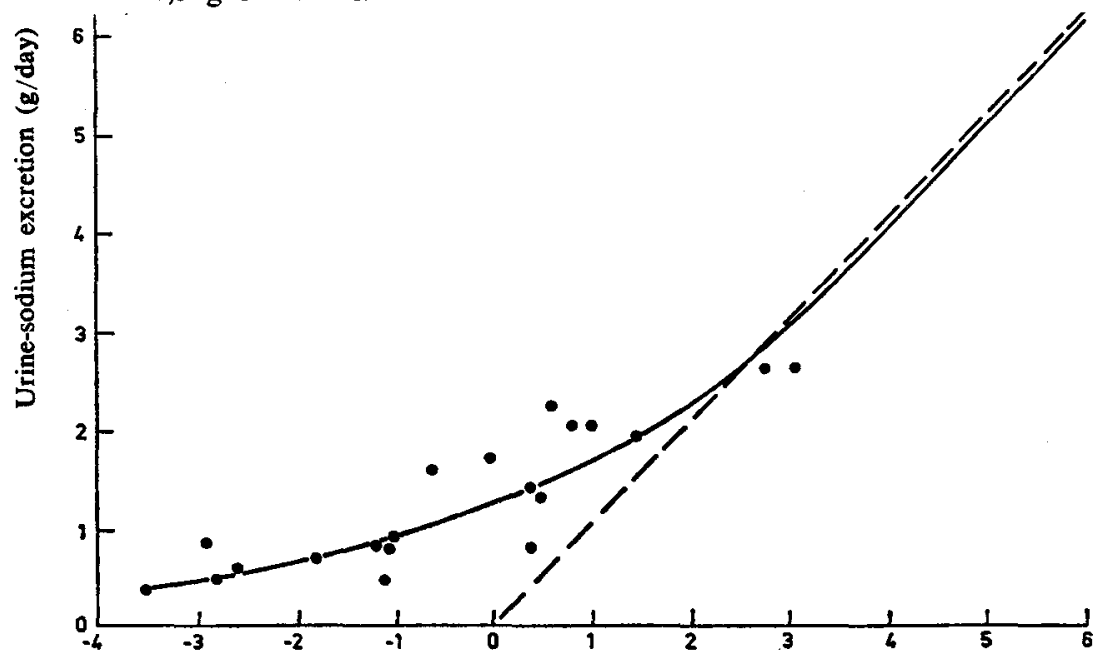

Na-intake minus Na-faeces minus Na-milk minus 2,5 g Na "other secretions"

With a daily urine-sodium excretion of approximately $3 \mathrm{~g}$ the total excretion of sodium according to FIG. 6 will be as high as the sodium intake, and the balance will be in equilibrium. When there is a minimum of $3 \mathbf{g}$ of "available sodium" minus sodium required for secretion in the milk and $2,5 \mathrm{~g}$ for "other excretions", retention will be zero. These $5,5 \mathrm{~g}$ of "available sodium" per day might be called the "maintenance requirement".

These data enable the estimation of the daily intake of herbage sodium, required by an adult animal to maintain a balance between the sodium ingested and that excreted. The little sodium in the drinking water has been left out of consideration. Secretion in the milk is estimated at $0,40 \mathrm{~g}$ of available sodium per litre, "maintenance requirement" at $5,5 \mathrm{~g}$ a day. The daily requirement of a dairy cow with a milk yield of 20 litres per day is therefore $(20 \times 0,40)+5,5 \mathrm{~g}=13,5 \mathrm{~g}$ of available sodium. In the preceding experiments with fresh herbage the average "availability" of the herbage sodium was $85 \%$, so that the daily requirement of herbage sodium should be $\frac{100}{85} \times 13,5=15,9 \mathrm{~g}$. This "availability" however may vary considerably, while also the milk yield has much influence on the daily requirement of herbage sodium. In TABLE 4 the sodium requirement has therefore been calculated for diverging values of "availability" and with various milk yields.

The results discussed in the preceding and the sodium requirements mentioned in TABLE 4 are based on balance trials of short duration. As far as sodium requirement is concerned, these experiments only indicate the minimum requirement. It will therefore be interesting to compare these results with those of prolonged experiments of SMITH and AINES (1959) with 30 dairy cows yielding 10.000 to 14.000 pounds of milk per year. These experiments lasting over 2 years comprised 4 groups of animals all receiving the same winter rations. The sodium intake averaged $9,5 \mathrm{~g}$ 
TABLE 4. Sodium requirement (g/day) of milking cows with various milk yields and differences in the utilization of herbage sodium

\begin{tabular}{cccccc}
\hline "Availability" & \multicolumn{5}{c}{ Sodium requirements in $\mathrm{g}$ /day for milk yields of } \\
\cline { 2 - 6 } & 10 & 15 & 20 & 25 & $30 \mathrm{~kg} / \mathrm{day}$ \\
$75 \%$ & 12,7 & 15,3 & 18,0 & 20,7 & 23,3 \\
$85 \%$ & 11,2 & 13,5 & 15,9 & 18,2 & 20,6 \\
$95 \%$ & 10,0 & 12,1 & 14,2 & 16,3 & 18,4 \\
\hline
\end{tabular}

per day. Three of the four groups received additional salt daily, i.e. $15 \mathrm{~g}, 60 \mathrm{~g}$ and $120 \mathrm{~g}$ of $\mathrm{NaCl}$ per day. Several criteria were used to assess the adequacy of inadequacy of salt intakes: daily feed consumption, body weight, an estimate of salt hunger, milk production, chemical analyses of feeds, blood, milk and urine. The cows without additional salt ration experienced salt hunger, lowered milk yields and losses in body weight. In this experiment it was evident that these symptoms could be counteracted by additional sodium supply and not by that of chloride (AINEs and SMrTH, 1957). In SMirh's and AINEs' experiment the long time required to develop serious deficiency symptoms was of particular interest. Although the cows with no additional salt ration showed early "signs of the deficiency" in terms of salt hunger and a sharply reduced excretion of sodium, it was not until approximately a year had passed that such adverse effects as loss in body weight, failure in appetite and a decline in milk production were observed. These animals only had $9,5 \mathrm{~g}$ of sodium per day, an amount at which according to our own investigations sodium deficiency was bound to occur. The group of cows supplemented with $15 \mathrm{~g}$ of $\mathrm{NaCl}$ per day did not show a decline in milk yield nor losses in body weight. The animals did show salt hunger and excreted very little sodium in the urine. According to the investigators these facts suggest that the optimal sodium requirement is somewhat higher than the sodium in the rations, supplemented by $15 \mathrm{~g}$ of $\mathrm{NaCl}$. For this reason a group of similar dairy cows was inserted, fed on the same rations supplemented however with $30 \mathrm{~g}$ of $\mathrm{NaCl}(=11,8 \mathrm{~g}$ of $\mathrm{Na})$ per day. At this sodium intake no deficiency symptoms were observed, even at long term. The authors accordingly have concluded that the optimal sodium requirement of these high yielding animals is approximately $9,5 \mathrm{~g}+11,8 \mathrm{~g}=21,3 \mathrm{~g}$ of sodium per day.

There appears to be a striking correspondence between the "optimal" sodium requirement of $21,3 \mathrm{~g}$ of sodium per day per animal with high milk yields as determined by SMITH and AINES (1959), and the minimum sodium requirements of $20,7 \mathrm{~g}$ (with a milk yield of 25 litres a day) and $23,3 \mathrm{~g}$ per day (with a yield of 30 litres a day) as determined by means of balance trials in the present publication. The fact that SMITH and Aines observed deficiency symptoms in cows with a sodium intake of $9,5 \mathrm{~g}$ a day and also in animals supplemented with $15 \mathrm{~g}$ of $\mathrm{NaCl}$, completely agrees with our findings on the sodium requirement. This suggests that the minimum sodium requirement as approximated by balance trials of short duration is about the same as the "optimal requirement" as calculated by means of data on prolonged feeding experiments by SMITH and AINEs (1959). 


\section{ACKNOWLEDGEMENT}

The author's thanks are due to Dr. Ir. A. J. H. vaN Es at the Laboratory of Animal Physiology, Agricultural University, Wageningen, and to Dr. C. C. Oosterlee of the Foundation for Bloodgroup Studies in Animals, Wageningen, for their valuable advices.

Aines, P. D., and S. E. SMITH

BABCOCK, S. M.

BARRison Villares, J., and L. A. Bertlett

BUNGE, G.

CunNingham, H. M.,

G. L. Frederick and

S. J. BRISON

Es, A. J. H. VAN, and

J. E. VoGT

Ferguson, K. A., and

D. F. Dowling

GroOT, TH. DE

GRUNERT, R. R.,

J. H. MEYER and

P. H. PhIllits

KEMP, A.

W. B. DEYs,

O. J. Hemkes and

A. J. H. vaN Es

MaNGOLD, E.

MilleR, H. G.

Mulder, H., A. J. van der 1959 HAve en C. J. Schipper

\section{REFER E N CES}

1957 Sodium versus chloride for the therapy of salt deficient dairy cows. J. Dairy Sci. 40, 682-688.

1905 The addition of salt to the ration of dairy cows. Wisconsin Agric. Exp. Sta. Rep. No. 22, 129-156.

1951 Bol. Industr. Anim. 12, 3 and 21.

1873 Zeitschr. f. Biol. 9, 104-143.

1955 Application of an inslatable urethrale catheter for urine collection from cows. J. Dairy Sci. 38, 997-1000.

1959 Separate collection of feces and urine of cows. J. Anim. Sci. 18, 1220-1223.

1955 The function of cattle sweat glands. Austr. J. Agric. Res. 6, $640-644$.

1961 Magnesium intake and utilization. Tijdschr. Diergeneesk. 19, 1265-1277.

1950 The sodium and potassium requirements of the rat for growth. J. Nutr. 42, 609-618.

1958 Influence of fertilizer treatment of grassland on the incidence of hypomagnesaemia and hypomagnesaemic tetany (grass tetany) in milking cows. Neth. J. agric. Sci. 6, 281-297.

1960 Hypomagnesaemia in milking cows: The response of serum magnesium to alterations in herbage composition resulting from potash and nitrogen dressings on pasture. Neth. J. agric. Sci. 8, 281-304.

1961 Hypomagnesaemia in milking cows : Intake and utilization of magnesium from herbage by lactating cows. Neth. J. agric. Sci. 9, 134-149.

1932 Handbuch der Ernährung und des Stoffwechsels der landwirtschaftlichen Nutztiere. III.

1923a Potassium in animal nutrition. I. Influence of potassium on urinary sodium and chlorine excretion. J. Biol. Chem. Vol. 55, 45-59.

1923b Potassium in animal nutrition. II. Potassium in its relation to the growth of young rats. J. Biol. Chem. Vol. 55, 61-68.

1926 Potassium in animal nutrition. III. Influence of potassium on total excretion of sodium, chlorine, calcium and phosphorus. J. Biol. Chem. Vol. 67, 71-77.

De samenstelling van Nederlandse melk. Lab. v. Zuivelber. Landb.hogesch. Wageningen. 
Renkema, J. A., Tatsudo Senshu, Blanche D. E. GaILlard and E. BrouWER

RICHARDS, M. B., W. GoDDEN and A. D. Husband

RICHARDS, M. B., W. GODDEN and A. D. Husband

Rook, J. A. F., and C. C. BALCH

SCHOORL, $P$. SMith, S. E., and P. D. AINES
1962 The activity of the intestinal wall of the cow in sodium homeostasis. Neth. J. agric. Sci. 10, 52-57.

1924 The influence of variations in the sodium-potassium ratio on the nitrogen and mineral metabolism of the growing pig. Biochem. J. 18, 651-660.

1927 The influence of variations in the sodium-potassium ratio on the nitrogen and mineral metabolism of the growing pig. II. Biochem. J. 21, 971-985.

1962 The intake and excretion of calcium, phosphorus, sodium, potassium, water and dry matter in relation to the development of hypomagnesaemia. J. agric. Sci. 59, 103-111.

1934 Natriumgebrek bij ratten. Thesis. Wageningen, 1934.

1959 Salt requirements of dairy cows. Cornell Univ. Agric. Exp. Sta., New York. Bull. No. 938. 